\title{
Obituary
}

\author{
Editor: Henry R. Rollin
}

\section{LISELOTTE FraNKL, formerly Director Anna Freud Centre, Hampstead, London}

Dr Liselotte Frankl died on the 12 October 1988 at the age of 78. She qualified as a psychologist in Vienna and became a lecturer at the University and Research Assistant to Charlotte Bühler, the first, and at that time the only, Professor of Child Development anywhere in Europe. Although Professor Bühler was strongly opposed to psychoanalytic thinking, Liselotte Frankl attended, more or less secretly, the lectures which Anna Freud was holding less than ten minutes' walk from the University. She was one of three of Bühler's assistants who later became psychoanalysts: the others were Esther Bick and Ilse Hellman. She gained her PhD at the same university in 1935 and began her personal analysis with Ernst Kris.

She was able, through the good offices of an organisation set up to help Jewish academics, to leave Germany in 1938 and to come to live and work in England. She decided to undertake a medical training which seemed to her, as a foreigner, a necessary condition for professional advancement. She was accepted at the Royal Free Hospital School of Medicine for Women, and spent part of her time as a medical student at the University of St Andrews, to which a part of the School was evacuated in 1940. In 1945 she obtained an MB BS with distinction from the University of London. While in London, she was able to continue her personal analysis and join the British Psycho-Analytical Society. She was appointed a training analyst a few years later and is remembered with affection by many of her trainees.

Following an appointment at the West Sussex Child Guidance Service, an important proportion of her professional career was spent as psychiatrist to the East London Child Guidance Clinic, a part of the London Hospital, where she worked in close association with Augusta Bonnard. Many students of the Child Training of the Hampstead Clinic (as the Anna Freud Centre was then called) were able to gain valuable clinical experience under her tutelage, and had cause to appreciate and be grateful for her deep insight into child assessment and development. She became a training analyst and supervisor on the Hampstead programme, and was appointed Medical Director of the Clinic - a post in which she served for many years. She undertook lecture tours in the United States in 1961 and 1964, and addressed meetings and led seminars in San Francisco, Denver and other major American centres. She also lectured throughout Europe on some of the many issues to which she had made important contributions.

She made some significant additions to existing knowledge of developmental psychology, general psychiatry and child psychoanalysis. In 1947, she published a study on personality change following prefrontal leucotomy, written jointly with the distinguished psychiatrist Mayer-Gross. She also published some interesting findings on the effect of swaddling on children in Rumania. Some of her papers were written in conjunction with Augusta Bonnard, Elizabeth Shepheard (now Model) and other colleagues, among them Ilse Hellman with whom she had a close working relationship at the Hampstead Clinic. She wrote on applications of psychoanalytic understanding to child psychotherapy, on problems of diagnosis and interview technique, on the ego's participation in the therapeutic alliance, on problems of adolescence, accident proneness, frustration tolerance and other topics which illustrated the broad range of her interests. She was elected a Foundation Fellow of the Royal College of Psychiatrists in 1971, and the Royal Society of Medicine was among the learned societies she addressed.

She was a remarkably perceptive and gifted diagnostician and no-one knew better than she how to draw the most out of an initial assessment interview. She had an uncanny ability to demonstrate how material gathered during an analysis was already foreshadowed in the initial assessment, in a way that owed nothing to retrospective understanding. To her colleagues at large, she was perhaps too retiring for her own good, but to those who knew her well her modesty hid a sense of fun and a real wit.

CY

\section{Olive Ballance InMan, formerly Visiting Psychotherapist, Graylingwell Hospital, Chichester}

Dr Inman studied medicine at the London School of Medicine for Women (as it was then known) and St Mary's Hospital, Paddington. She qualified MRCS, LRCP in 1919 and took the MB BS London in 1922. 